\title{
Pemahaman Konsep Siswa Kelas IV melalui Pembelajaran Inkuiri Terbimbing tentang Materi Sifat-Sifat Cahaya
}

\author{
Verdiana Somi Koten ${ }^{1}$, Suharti $^{2}$, Sutopo \\ ${ }^{1}$ Pendidikan Dasar-Universitas Negeri Malang \\ ${ }^{2}$ Pendidikan Kimia-Universitas Negeri Malang \\ ${ }^{3}$ Pendidikan Fisika-Universitas Negeri Malang
}

\begin{tabular}{l} 
INFO ARTIKEL \\
\hline Riwayat Artikel: \\
Diterima: 11-03-2019 \\
Disetujui: 11-09-2019 \\
\hline Kata kunci: \\
concept understanding; \\
guided inquiry; \\
the properties of light; \\
pemahaman konsep; \\
inkuiri terbimbing; \\
sifat-sifat cahaya
\end{tabular}

Alamat Korespondensi:

Verdiana Somi Koten

Pendidikan Dasar

Universitas Negeri Malang

Jalan Semarang 5 Malang

E-mail: kotenverdiana21@gmail.com

\begin{tabular}{l} 
ABSTRAK \\
\hline Abstract: This study aims to examine the effect of guided inquiry learning models on the \\
understanding concepts of students. This research was conducted at SDK Sta. Maria \\
Assumpta Kupang, NTT. The understanding concepts of the students about the properties \\
of light is measured using multiple choices the questions. The results of the study show \\
that understanding students' science concepts can be improved by using a guided inquiry \\
learning model. \\
Abstrak: Penelitian ini bertujuan untuk meneliti pengaruh model pembelajaran inkuiri \\
terbimbing terhadap pemahaman konsep siswa. Penelitian ini dilakukan di SDK Sta. \\
Maria Assumpta Kupang, NTT. Pemahaman konsep siswa tentang cahaya diukur \\
menggunakan soal tes berbentuk pilihan ganda. Hasil penelitian menunjukkan bahwa \\
pemahaman konsep IPA siswa meningkat dengan menggunakan model pembelajaran \\
inkuiri terbimbing.
\end{tabular}

Kurikulum 2013 menekankan pola pembelajaran yang berpusat pada pendidik (teacher centered) menjadi pembelajaran berpusat pada peserta didik (student centered), (Widyastono, 2014). Perubahan proses pembelajaran tercermin pada perubahan kegiatan belajar mengajar. Kegiatan belajar mengajar saat ini dituntut untuk lebih menekankan pada dimensi sosial dan konstruktivistik (Tegeh, 2009). Siswa diharapkan tidak hanya mencatat dan menghafal materi yang diperoleh melainkan siswa dituntut untuk mengonstruk pengetahuannya sendiri. Melalui pengetahuan dan pengalaman yang dimiliki, siswa diharapkan dapat mencari solusi dalam memecahkan masalah. Pembelajaran akan menjadi lebih menyenangkan, apabila siswa dapat mengonstruk pemahamannya dan menemukan jawaban. Proses belajar konstruktivistik adalah proses dimana siswa membangun pemahaman sendiri lewat pengalamannya sehari-hari sehingga proses konsepsi dan perubahan konseptual siswa meningkat. Oleh sebab itu, banyak penelitian yang menganjurkan atau menyarankan agar pembelajaran yang terjadi di sekolah ialah pembelajaran yang berpusat pada siswa, salah satunya dengan menggunakan inkuiri terbimbing (Kang \& Keinonen, 2018).

Keunggulan inkuiri terbimbing menurut (Suryosubroto, 2002) (1) siswa dapat mengembangkan dan menuasai keterampilan dan proses kognitif; (2) pengetahuan siswa terhadap suatu materi lebih kuat dan mendalam; (3) meningkatkan gairah belajar siswa; (4) siswa diberi kesempatan untuk menunjukkan kemampuannya; (5) siswa menjadi terlibat dan termotivasi dalam belajar; (6) siswa menjadi lebih percaya diri; (7) pembelajaran yang berpusat pada siswa dan pendidik sebagai teman belajar.

Penelitian ini menerapkan model pembelajaran inkuiri terbimbing pada topik cahaya. Cahaya adalah salah satu bentuk energi yang dipancar oleh benda dalam bentuk gelombang elektromagnetik. Sumber cahaya adalah benda-benda yang dapat memancarkan cahaya, seperti matahari, bintang, lampu maupun api. Tanpa ada cahaya maka tidak ada kehidupan, oleh sebab itu cahaya sangat penting bagi kehidupan. Topik cahaya tidak bisa dipahami hanya dengan membaca ataupun mendengarkan cerita, melainkan dengan melakukan percobaan-percobaan atau eksperimen sehingga siswa berperan aktif dalam pembelajaran dan secara maksimal dapat mencari dan menemukan sendiri jawaban dari pertanyaan atau masalah yang diberikan. Penelitian ini dilakukan di kelas IV SDK Sta. Maria Assumpta, Kupang NTT. Fase-fase inkuiri terbimbing yang digunakan dalam penelitian ini diadaptasi dari (Llewellyn, 2013) dapat dilihat pada tabel 1. 
Tabel 1. Fase Model Inkuiri Terbimbing

\begin{tabular}{|c|c|c|}
\hline Kegiatan & Kegiatan Guru & Kegiatan Siswa \\
\hline \multicolumn{3}{|c|}{ Pertanyaan } \\
\hline Mengeksplorasi fenomena & $\begin{array}{l}\text { Menggali kemampuan awal siswa dengan } \\
\text { mengungkapkan peristiwa. }\end{array}$ & $\begin{array}{l}\text { Menunjukkan kemampuan awal terkait } \\
\text { peristiwa yang diamati. }\end{array}$ \\
\hline Memfokuskan pertanyaan & $\begin{array}{l}\text { Membimbing siswa } \\
\text { merumuskan pertanyaan. }\end{array}$ & Merumuskan pertanyaan \\
\hline \multicolumn{3}{|l|}{ Prosedur } \\
\hline Merencanakan investigasi & $\begin{array}{l}\text { Memfasilitasi siswa untuk merancang investigasi } \\
\text { dalam pengumpulan data. }\end{array}$ & $\begin{array}{l}\text { Merancang investigasi untuk mengumpulkan } \\
\text { data. }\end{array}$ \\
\hline Melaksanakan investigasi & $\begin{array}{l}\text { Memfasilitasi siswa untuk } \\
\text { melakukan investigasi }\end{array}$ & $\begin{array}{l}\text { Melakukan investigasi untuk mengumpulkan } \\
\text { data yang dibutuhkan }\end{array}$ \\
\hline \multicolumn{3}{|l|}{ Hasil } \\
\hline $\begin{array}{l}\text { Menganalisis data dan } \\
\text { bukti }\end{array}$ & $\begin{array}{l}\text { Membimbing siswa untuk menginterpretasi data } \\
\text { yang telah diperoleh. }\end{array}$ & $\begin{array}{l}\text { Menginterpretasi informasi dari data yang } \\
\text { diperoleh, membuat kesimpulan awal } \\
\text { berdasarkan data. }\end{array}$ \\
\hline $\begin{array}{l}\text { Membangun pengetahuan } \\
\text { baru }\end{array}$ & $\begin{array}{l}\text { Membimbing siswa untuk mengaitkan informasi baru } \\
\text { yang diperoleh dan hubungannya dengan } \\
\text { pengetahuan awalnya. }\end{array}$ & $\begin{array}{l}\text { Menghubungkan informasi baru dengan } \\
\text { pengetahuan awal yang telah diperoleh. }\end{array}$ \\
\hline $\begin{array}{l}\text { Mengomunikasikan } \\
\text { pengetahuan baru }\end{array}$ & Memfasilitasi diskusi hasil investigasi kelas & $\begin{array}{l}\text { Mengomunikasikan hasil investigasi di dalam } \\
\text { kelas dan mendiskusikannya. }\end{array}$ \\
\hline
\end{tabular}

Sumber: Llewellyn (2013)

\section{METODE}

Penelitian ini dilaksanakan di SDK Sta. Maria Assumpta, Kota Baru, Kupang. Subjek penelitian ini adalah kelas IV. Pada saat penelitian, peneliti membentuk team pengajar dengan wali kelas IVA dan IV B. Pembelajaran di kelas kontrol dilakukan dengan menggunakan metode konvensional yang bertolak belakang dengan pembelajaran dikelas eksperimen, seperti yang sudah dipaparkan sebelumnya. Pelaksanaan pembelajaran pada kelas kontrol biasanya didominasi oleh pendidik. Pembelajaran yang terjadi kurang mengajak siswa untuk aktif melainkan siswa seringkali merasa bosan dan bahkan menganggap bahwa pelajaran IPA adalah pelajaran yang sulit. Pendidik kurang kreatif dalam mengembangkan instrumen pembelajaran. Pendidik lebih memilih untuk mencontoh dari buku pelajaran yang digunakan. Pembelajaran yang dilakukan di kelas IVA (kelas eksperimen) menggunakan inkuiri terbimbing dan pembelajaran ini siswa akan melewati tujuh fase. Fase pertama siswa diajak untuk mengamati fenomena alam yang terjadi di lingkungan sekitar, antara lain mengamati sinar matahari yang masuk lewat jendela. Fase kedua, dimana siswa diberi pertanyaan berdasarkan pengamatan yang telah dilakukan kemudian diberikan kesempatan untuk menjawab pertanyaan. Pada fase ketiga siswa akan merencanakan dan fase keempat melaksanakan investigasi, siswa dibimbing untuk menyiapkan semua yang dibutuhkan untuk melakukan eksperimen, serta melakukan eksperimen sesuai dengan prosedur telah disiapkan. Siswa kemudian melakukan percobaan, menganalisis data, membuat kesimpulan dari hasil percobaan dan akhirnya mengomunikasikan hasil diskusi. Pada tahap akhir adalah post-test pemahaman konsep. Berdasarkan pemaparan di atas, maka kami secara singkat akan menggambarkan teori dan penelitian yang terkait dengan peningkatan pemahaman konsep IPA siswa melalui model inkuiri terbimbing.

Data pemahaman konsep siswa dikumpulkan dengan menggunakan instrumen test yang telah melalui proses validasi dari dosen ahli dan diuji cobakan kepada siswa untuk mendapatkan tingkat reliabilitas dan tingkat validitas instrumen test. Hasil uji coba butir instrumen tes yang reliabel dan valid digunakan untuk pengambilan data penelitian. Soal yang digunakan sebanyak 20 butir soal yang terdiri dari empat indikator yang harus dikuasai oleh siswa. Indikator-indikator yang harus dikuasai oleh siswa yaitu, mengidentifikasi sifat-sifat cahaya, mengklasifikasi benda bening, menyebutkan benda bening dan benda gelap, menjelaskan bunyi hukum pemantulan cahaya. Analisis data dalam penelitian ini digunakan untuk mencari uji beda $N$-Gain .

HASIL

Tabel 2. Deskripsi Data Skor Pemahaman Konsep Siswa

\begin{tabular}{lcccccc}
\hline \multirow{2}{*}{ Statistik } & \multicolumn{3}{c}{ Kelas Eksperimen } & \multicolumn{3}{c}{ Kelas Kontrol } \\
\cline { 2 - 7 } & Pre-Test & Post-Test & N-Gain & Pre-Test & Post-Test & N-Gain \\
\hline N & 30 & 30 & 30 & 30 & 30 & 30 \\
Skor Minimum & 40 & 75 & 0,55 & 30 & 60 & 0,38 \\
Skor Maksimum & 60 & 95 & 0,89 & 50 & 85 & 0,75 \\
Mean & 47,33 & 83,83 & 0,7012 & 41,33 & 72,50 & 0,5356 \\
Standar Deviasi & 5,833 & 6,783 & 0,10540 & 5,561 & 7,041 & 0,08884 \\
\hline
\end{tabular}


Data pada tabel 2 menunjukkan bahwa terjadi peningkatan pada kelas eksperimen dibandingkan dengan kelas kontrol. Hasil analisis $N$-gain menunjukkan $N$-gain kelas eksperimen sebesar 0,70 dan kelas kontrol 0,54. Secara statistik, perbedaan dari data diatas dapat digambarkan pada tabel 3.

Tabel 3 Uji-t Pemahaman Konsep Siswa

\begin{tabular}{ccccc}
\hline \multirow{2}{*}{ Pemahaman Konsep IPA Siswa } & \multicolumn{2}{c}{$\boldsymbol{N}$-Gain Skor } & \multirow{2}{*}{ Uata-rata } & \multirow{2}{*}{ Kesimpulan } \\
\cline { 2 - 3 } & Kelas Eksperimen & Kelas Kontrol & & \\
\hline Uji Beda $N$-Gain & 0,70 & 0,54 & 0,000 & Berbeda \\
\hline
\end{tabular}

\section{PEMBAHASAN}

Hasil uji $N$-Gain menunjukkan bahwa terdapat perbedaan pemahaman konsep siswa pada kedua kelas. Hasil analisis $N$ gain pada kelas eksperimen adalah 0,70, sedangkan untuk kelas kontrol adalah 0,54. Keduanya berada pada kategori sedang. Pemahaman konsep pada kelas eksperimen lebih tinggi dari kelas kontrol. Hal ini dibuktikan dengan jumlah siswa pada kelas eksperimen yang mampu menjawab soal yang diberikan lebih banyak dari kelas kontrol. Dari hasil pekerjaan siswa terlihat bahwa siswa mampu mengidentifikasi dan menganalisis apa yang diketahui dari soal. Pada kelas eksperimen $80 \%$ siswa dapat menjawab soal-soal tersebut, sedangkan pada kontrol siswa yang dapat menjawab soal tersebut sebesar 50\%. Berdasarkan hasil penelitian siswa pada kelas eksperimen dapat menjawab soal-soal tersebut karena siswa pada kelas eksperimen dapat mengonstruk pemahamannya dengan lebih baik. Pembelajaran di kelas kontrol yang masih berpusat pada pendidik, mengakibatkan kemampuan siswa dalam menganalisis soal yang diberikan tidak berkembang dengan baik. Siswa pada kelas kontrol pada saat pembelajaran terlihat pasif, hanya mendengarkan ceramah dari pendidik sehingga mereka lebih menghafal materi yang diberikan, tetapi tidak memahami konsep dari materi tersebut. Dengan banyaknya jumlah siswa yang menjawab benar pada kelas eksperimen dapat diketahui bahwa tingkat pemahaman konsep semakin meningkat. Siswa tidak hanya terlibat aktif melainkan lebih memahami konsep dari materi yang diberikan oleh pendidik.

Hasil penelitian ini membuktikan bahwa siswa pada kelas eksperimen memiliki pemahaman konsep yang lebih tinggi. Hasil penelitian ini didukung dan diperkuat dengan pendapat (Tangkas, 2012; Trundle, Atwood, Christopher, \& Sackes, 2010) mengungkapkan bahwa terdapat pengaruh pemahaman konsep IPA siswa yang diajar menggunakan model pembelajaran inkuiri terbimbing dengan pengajaran tradisional. Penggunaan model pembelajaran inkuiri terbimbing dapat meningkatkan pemahaman konsep IPA siswa secara efektif (Banerjee, 2010; Dorfman, Issachar, \& Zion, 2017; Marsudiatmi \& WA, 2013; Sarwi, Sutardi, \& Prayitno, 2016; Setyawati, Candiasa, Kom, \& Yudana, 2014). Dari hasil analisis tersebut diketahui bahwa secara klasikal terjadi peningkatan pada kelas eksperimen. Model inkuiri terbimbing tidak hanya mampu meningkatkan pemahaman konsep peserta didik, tetapi juga dapat mengembangkan nilai karaketer konservasi siswa. (Kang \& Keinonen, 2018) menyatakan bahwa pemahaman konsep siswa yang dibelajarkan dengan menggunakan pendekatan pembelajaran yang berbasis pada siswa terkhususnya model inkuiri terbimbing berbeda dengan dengan siswa yang dibelajarkan dengan metode konvensional. Melalui pembelajaran inkuiri terbimbing pemahaman konsep siswa akan semakin meningkat dan berperan aktif didalam proses pembelajaran. Penelitian oleh (Koretsky, Keeler, Ivanovitch, \& Cao, 2018) menunjukkan bahwa terdapat keterlibatan siswa didalam pembelajaran atau siswa lebih aktif dalam pembelajaran dan efektif untuk meningkatkan proses berpikir siswa. Penelitian oleh (Chan, Yang, Maliska, \& Grünbaum, 2012) menunjukkan bahwa penggunaan model inkuiri terbimbing berbantuan komputer membantu menumbuhkan pemahaman konsep siswa terkait materi sains.

Hasil pengamatan menunjukkan bahwa pembelajaran yang terjadi di kelas masih kurang kondusif karena siswa banyak membutuhkan bimbingan dari pendidik. Siswa juga belum dipersiapkan dengan baik mentalnya untuk menerima pembelajaran dengan menggunakan model inkuiri, gaya belajar siswa yang lama masih terbawa, serta iklim pembelajaran di kelas yang terasa kaku dikarenakan yang mengajarkan materi pada kelas eksperimen adalah peneliti. Pernyataan ini diperkuat dengan pendapat dari Suryosubroto (2009) yang menyatakan bahwa model inkuiri juga memiliki kelemahan, seperti (1) siswa harus memiliki kesiapan mental dalam belajar; (2) kurang berhasil di kelas besar; (3) terkesan terlalu idealis karena lebih mementingkan aspek kognitif, afektif, dan psikomotor; (4) siswa lebih nyaman dengan gaya belajar yang lama; (5) sulit mengontrol keberhasilan dan kegiatan siswa. Kendala-kendala yang dialami pendidik di lapangan mengakibatkan peningkatan pemahaman konsep siswa tentang materi yang diajarkan tidak terlalu maksimal.

\section{SIMPULAN}

Pemahaman konsep siswa dapat ditingkatkan dengan menggunakan model pembelajaran inkuiri terbimbing. Hasil penelitian yang telah dilakukan pada SDK Sta. Maria Assumpta Kupang menunjukkan bahwa terdapat perbedaan $N$-Gain pada kelas kontrol dan kelas eksperimen. Kelas eksperimen menggunakan model pembelajaran inkuiri terbimbing, sedangkan kelas kontrol menggunakan metode konvensional. Secara klasikal, $\mathrm{N}$-Gain pada kelas eksperimen 0,70 dan kelas kontrol 0,54 yang berarti model pembelajaran inkuiri terbimbing berpengaruh pada pemahaman konsep siswa. 
Pembelajaran inkuiri terbimbing dapat ditingkatkan dengan cara menyiapkan mental siswa dengan baik sehingga hasil yang diperoleh dapat maksimal. Pendidik juga harus memberikan kepercayaan dan menumbuhkan rasa percaya diri siswa sehingga siswa dapat mengonstruk pengetahuannya sendiri lewat pengalaman nyata.

\section{DAFTAR RUJUKAN}

Banerjee, A. (2010). Teaching Science Using Guided Inquiry as the Central Theme: A Professional Development Model for High School Science Teachers. National Science Education Leadership Association.

Chan, K. Y. K., Yang, S., Maliska, M. E., \& Grünbaum, D. (2012). An Interdisciplinary Guided Inquiry on Estuarine Transport Using a Computer Model in High School Classrooms. The American Biology Teacher, 74(1), $26-33$.

Dorfman, B. S., Issachar, H., \& Zion, M. (2017). Yesterday's Students in Today's World-Open and Guided Inquiry Through the Eyes of Graduated High School Biology Students. Research in Science Education, 1-27. https://doi.org/https://doi.org/10.1007/s11165-017-9683-6

Kang, J., \& Keinonen, T. (2018). The Effect of Student-Centered Approaches on Students' Interest and Achievement in Science: Relevant Topic-Based, Open and Guided Inquiry-Based, and Discussion-Based Approaches. Research in Science Education, 48(4), 865-885. https://doi.org/DOI 10.1007/s11165-016-9590-2

Koretsky, M., Keeler, J., Ivanovitch, J., \& Cao, Y. (2018). The Role of Pedagogical Tools in Active Learning: A Case for Sense-Making. International Journal of STEM Education, 5(1), 18. https://doi.org/https://doi.org/10.1186/s40594-0180116-5

Llewellyn, D. (2013). Teaching High School Science Through Inquiry and Argumentation. Corwin Press.

Marsudiatmi, L., \& WA, S. (2013). Pengaruh Model Pembelajaran Inkuiri Terbimbing (Guided Inquiry) terhadap Pemahaman Konsep IPA Materi Cahaya Ditinjau dari Motivasi Belajar. Jurnal Didaktika Dwija Indria, 1(5).

Sarwi, S., Sutardi, S., \& Prayitno, W. W. (2016). Implementation of Guided Inquiry Physics Instruction to Increase an Understanding Concept and to Develop the Students'Character Conservation. Jurnal Pendidikan Fisika Indonesia, 12(1), $1-7$.

Setyawati, N. W. I., Candiasa, I. M., Kom, M. I., \& Yudana, I. M. (2014). Pengaruh Model Pembelajaran Inkuiri Terbimbing terhadap Pemahaman Konsep dan Keterampilan Proses Sains Siswa Kelas XI IPA SMA Negeri 2 Kuta Kabupaten Badung. Jurnal Administrasi Pendidikan Indonesia, 5(1).

Suryosubroto, B. (2002). Proses Belajar Mengajar di Sekolah Wawasan Baru: Beberapa Metode Pendukung dan Beberapa Komponen Layanan Khusus. Jakarta: PT Rineka Cipta.

Tangkas, I. M. (2012). Pengaruh Implementasi Model Pembelajaran Inkuiri Terbimbing terhadap Kemampuan Pemahaman Konsep dan Keterampilan Proses Sains Siswa Kelas X SMAN 3 Amlapura. Jurnal Pendidikan dan Pembelajaran IPA Indonesia, 2(1).

Tegeh, I. (2009). Perbandingan Prestasi Belajar Mahasiswa yang Diajar dengan menggunakan Problem Based-Learning dan Ekspositori yang Memiliki Gaya Kognitif Berbeda. Disertasi tidak diterbitkan. Universitas Negeri Malang, Malang.

Trundle, K. C., Atwood, R. K., Christopher, J. E., \& Sackes, M. (2010). The Effect of Guided Inquiry-Based Instruction on Middle School Students' Understanding of Lunar Concepts. Research in Science Education, 40(3), 451-478. https://doi.org/DOI 10.1007/s11165-009-9129-x

Widyastono, H. (2014). Pengembangan Kurikulum di Era Otonomi Daerah: Dari Kurikulum 2004, 2006 ke Kurikulum 2013. Jakarta: Bumi Aksara. 